\title{
Progression of the silicate cathode materials used in lithium ion batteries
}

\author{
BAO LiYing ${ }^{1,2}$, GAO Wei ${ }^{1}$, SU YueFeng ${ }^{1,2^{*}}$, WANG Zhao ${ }^{1}$, LI Ning $^{1}$, CHEN Shi $^{1,2}$ \& \\ WU Feng ${ }^{1,2}$
}

\footnotetext{
${ }^{1}$ School of Chemical Engineering and Environment, Beijing Institute of Technology, Beijing 100081, China;

${ }^{2}$ National Development Center of High Technology Green Materials, Beijing 100081, China
}

Received June 28, 2012; accepted October 29, 2012; published online December 11, 2012

\begin{abstract}
Poly anionic silicate materials, which demonstrate a high theoretical capacity, high security, environmental friendliness and low-cost, are considered one of the most promising candidates for use as cathode materials in the next generation of lithium-ion batteries. This paper summarizes the structure and performance characteristics of these materials. The effects of different synthesis methods and calcination temperature on the properties of these materials are reviewed. Materials that demonstrate low conductivity, poor stability, cationic disorder or other drawbacks, and the use of various modification techniques, such as carbon-coating or compositing, elemental doping and combination with mesoporous materials, are evaluated as well. In addition, further research topics and the possibility of using these kinds of cathode materials in lithium-ion batteries are discussed.
\end{abstract}

lithium-ion batteries, silicate cathode materials, synthesis, performance optimization

Citation: Bao L Y, Gao W, Su Y F, et al. Progression of the silicate cathode materials used in lithium ion batteries. Chin Sci Bull, 2013, 58: 575-584, doi: $10.1007 / \mathrm{s} 11434-012-5583-3$

For the past few years, lithium transition-metal orthosilicates $\left(\mathrm{Li}_{2} \mathrm{MSiO}_{4}, \mathrm{M}=\mathrm{Fe}, \mathrm{Co}, \mathrm{Mn}\right)$ have been characterized as potential cathode materials for use in Li-ion batteries by some researchers. The strong Si-O bond allows this material to demonstrate good security. These orthosilicates are different from lithium transition-metal phosphates which only have one $\mathrm{Li}$ ion per formula unit. $\mathrm{Li}_{2} \mathrm{MSiO}_{4}$ with two $\mathrm{Li}$ ions per formula unit $\left(\mathrm{M}^{2+} \rightarrow \mathrm{M}^{4+}\right)$ could have a theoretical capacity that is $>300 \mathrm{~mA} \mathrm{~h} \mathrm{~g}^{-1}$. Therefore, its theoretical capacity and excellent safety performance could allow $\mathrm{Li}_{2} \mathrm{MSiO}_{4}$ to be used in potential toward the development of Li-ion batteries [1-6]. $\mathrm{Li}_{2} \mathrm{CoSiO}_{4}$ has a high theoretical capacity, but its second Li-ion deintercalation voltage plateau at about $5.0 \mathrm{~V}$ makes this difficult to achieve [1]. In addition, $\mathrm{Co}$ is expensive and environmentally toxic. So $\mathrm{Li}_{2} \mathrm{MnSiO}_{4}$ and $\mathrm{Li}_{2} \mathrm{FeSiO}_{4}$ have attracted more attention. This paper reviews the past few years of research progress in the field of $\mathrm{Li}_{2} \mathrm{Mn} / \mathrm{FeSiO}_{4}$ materials, and summarizes the

*Corresponding author (email: suyuefeng@ @it.edu.cn) methods that could be used to improve their electrochemical properties.

\section{Overview of $\mathrm{Li}_{2} \mathrm{Mn} / \mathrm{FeSiO}_{4}$ cathode materials}

Generally, the extraction of $\mathrm{Li}$ atoms from $\mathrm{Li}_{2} \mathrm{FeSiO}_{4}$ is not possible due to electron-redox coupling of $\mathrm{Fe}^{2+} / \mathrm{Fe}^{3+}$. The theoretical capacity is considered to be $166 \mathrm{~mA} \mathrm{~h} \mathrm{~g}^{-1}$ and the voltage platform is $3.1 \mathrm{~V}$. Phase-pure $\mathrm{Li}_{2} \mathrm{FeSiO}_{4}$ was successfully prepared by Nyten et al. [2]. The initial charge capacity of $165 \mathrm{~mA} \mathrm{~h} \mathrm{~g}^{-1}$ (99\% of the theoretical value) can be stabilized to around $140 \mathrm{~mA} \mathrm{~h} \mathrm{~g}^{-1}$ ( $84 \%$ of the theoretical value) after a few cycles, and the initial discharge capacity is $130 \mathrm{~mA} \mathrm{~h} \mathrm{~g}$. The results of the cyclic voltammogram suggest that phase transition is more stable after the first cycle. This involves a structural ordering process from a solid solution to a long-range-ordered structure. $\mathrm{Li}_{2} \mathrm{MSiO}_{4}$ $(\mathrm{M}=\mathrm{Mn}, \mathrm{Fe})$ was successfully prepared using a modified Pechini process by Dominko et al. [3]. During the process 
of charging/discharging, the structure of $\mathrm{Li}_{2} \mathrm{FeSiO}_{4}$ demonstrates only minor changes, equivalent of two fully reversible phase changes, so this material demonstrates good cycling performance. Deng et al. [4] suggested that the changes induced by exposure to air are entirely reversible. Air-exposed $\mathrm{Li}_{2} \mathrm{FeSiO}_{4}$ regenerates by calcining at $700^{\circ} \mathrm{C}$ for $4 \mathrm{~h}$, demonstrating a similar structure, surface and electrochemical characteristics as the original sample. However, $\mathrm{Li}_{2} \mathrm{FeSiO}_{4}$ demonstrates very low electrical conductivity in the insulator range [5] and a value of $6 \times 10^{-14} \mathrm{~S} \mathrm{~cm}^{-1}$ at room temperature has been reported. This leads to the poor rate capacity of $\mathrm{Li}_{2} \mathrm{FeSiO}_{4}$ materials, which is the main problem researchers are currently facing [6].

$\mathrm{Li}_{2} \mathrm{MnSiO}_{4}$ is another cathode material that possesses a high theoretical capacity of $333 \mathrm{~mA} \mathrm{~h} \mathrm{~g}^{-1}$, and it is possible to extract two $\mathrm{Li}$ atoms at least theoretically from $\mathrm{Li}_{2} \mathrm{MnSiO}_{4}(\mathrm{Mn}[\mathrm{II}] / \mathrm{Mn}[\mathrm{III}]$ and $\mathrm{Mn}[\mathrm{III}] / \mathrm{Mn}[\mathrm{IV}])$, and it is theoretically easier to achieve a high specific capacity in cathode materials. $\mathrm{Li}_{2} \mathrm{MnSiO}_{4}$ was successfully prepared using a modified Pechini process by Dominko et al. [3]. The fact is that under the present conditions $\left(\mathrm{C} / 30,60^{\circ} \mathrm{C}\right)$ only about $0.6 \mathrm{Li}$ is reversibly exchanged in the first cycle. In the next cycles, the reversible capacity fades considerably to only about 0.3 reversibly exchanged $\mathrm{Li}$ by the fifth cycle. $\mathrm{Li}_{2} \mathrm{MnSiO}_{4} / \mathrm{C}$ composite materials were successfully prepared by Paromita et al. [7], and cyclic voltammetry demonstrated two oxidation/reduction couplings at 3.6/2.9 and 4.5/4.3 V with good reversibility. At the present, $\mathrm{Li}_{2} \mathrm{MnSiO}_{4}$ cathode materials demonstrate poor cycle stability and low conductivity. In the long run, silicate materials have good developmental prospects.

\section{Structure and performance characteristics of $\mathrm{Li}_{2} \mathrm{Mn} / \mathrm{FeSiO}_{4}$}

Three possible $\mathrm{Li}_{2} \mathrm{MnSiO}_{4}$ forms have been considered for crystallizing the Pmnb, Pmn $2_{1}\left(\beta-\mathrm{Li}_{3} \mathrm{PO}_{4}\right.$ derivatives) and $P 2_{1} / n\left(\gamma-\mathrm{Li}_{3} \mathrm{PO}_{4}\right.$ derivatives) space groups. Politaev et al. [8] synthesized $\mathrm{Li}_{2} \mathrm{MnSiO}_{4}$ and found that the crystal structure of $\mathrm{Li}_{2} \mathrm{MnSiO}_{4}$ is monoclinic within space group $P 2_{1} / n$ ( $\left.a=6.3368[1], b=10.9146[2], c=5.0730[1] \AA, \beta=90.987^{\circ}[1]\right)$. Arroyoy de Dompablo et al. [9,10] pointed out that the denser Pmn2 $2_{1}$ polymorph can be obtained by high-pressure and high-temperature treatment of the $P 2_{1} / n$ and $P m n b$ polymorphs or their mixtures, but $P m n 2_{1}$ is still stable even at $80 \mathrm{kbar}$ and $900^{\circ} \mathrm{C}$. Therefore, $\mathrm{Li}_{2} \mathrm{MnSiO}_{4}$ is usually described as an orthorhombic structure within space group $P m n 2_{1}$. As shown in Figure 1, it can be considered that the $\left[\mathrm{SiMnO}_{4}\right]$ layer infinites along the $a c$, and the $\mathrm{LiO}_{4}$ tetrahedron is linked together along the $b$-axis. In these layers, the $\mathrm{SiO}_{4}$ tetrahedron and $\mathrm{MnO}_{4}$ tetrahedron are connected by total points. The $\mathrm{Li}$ ion holds two $\left[\mathrm{SiMnO}_{4}\right]$ layers of the tetrahedron between these positions. In such a structure, where three $\mathrm{LiO}_{4}$ tetrahedron $\mathrm{O}$ atoms are in the same layer,

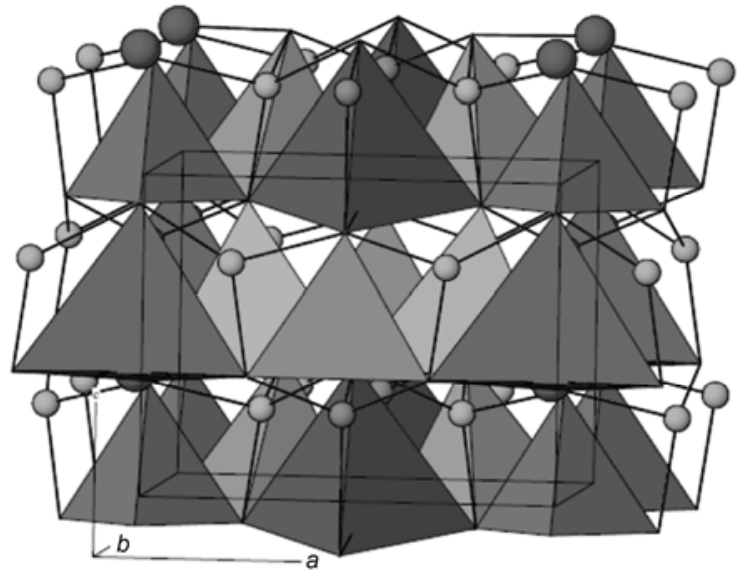

Figure 1 Crystal structure of $\mathrm{Li}_{2} \mathrm{MnSiO}_{4}$ shown in its polyhedral representation. Reprinted from [3] with permission from Elsevier.

the fourth ion is in the adjacent layer of $\mathrm{O}$. The $\mathrm{LiO}_{4}$ tetrahedron, with its total points along the axis linked together, allows the $\mathrm{Li}$ ion to complete the embedded emergency response. $\mathrm{Li}_{2} \mathrm{FeSiO}_{4}$ is isostructural with $\mathrm{Li}_{2} \mathrm{MnSiO}_{4}$ crystallizing the $P m n 2_{1}$ space group, demonstrating better stability during the processes of charging and discharging.

The strong Si-O bond allows poly anionic silicate materials to demonstrate good security. Dominko et al. [11] studied $\mathrm{Li}_{2} \mathrm{FeSiO}_{4} / \mathrm{C}$ and $\mathrm{Li}_{2} \mathrm{MnSiO}_{4} / \mathrm{C}$ cathode materials and found that the oxidation state of $\mathrm{Mn}$ in $\mathrm{Li}_{2} \mathrm{MnSiO}_{4} / \mathrm{C}$ cathode materials changes from the initial $\mathrm{Mn}$ (II) state to $\mathrm{Mn}(\mathrm{III})$ with a potential range of 4.0 to $4.5 \mathrm{~V}$. During oxidation, the short $\mathrm{Mn}-\mathrm{O}$ bond decreases from 2.04 to $1.87 \AA$ in correlation with the increase in the $\mathrm{Mn}$ valence state, while the larger $\mathrm{Mn}-\mathrm{O}$ distance of the $\mathrm{MnO}_{4}$ tetrahedron remains unchanged. This indicates that the related changes in the local environment of $\mathrm{Mn}$ are irreversible. The position of $\mathrm{Fe}$ in the slightly distorted $\mathrm{O}$ tetrahedra shifts as the valence changes accompanies the removal of $\mathrm{Li}$, therefore, the cycling stability of $\mathrm{Li}_{2} \mathrm{FeSiO}_{4} / \mathrm{C}$ has been confirmed. Dominko et al. [12] reduced the particle size of synthesized $\mathrm{Li}_{2} \mathrm{MnSiO}_{4}$, observing structural changes during the first charge that indicated the complete loss of peaks when reaching the nominal composition of ca. $\mathrm{Li}_{1} \mathrm{MnSiO}_{4}$. These peaks were not recovered during subsequent cycles. It is believed that the extraction of $\mathrm{Li}$ causes significant structural changes, so that the resulting material is only able to reversibly exchange a limited amount of Li. Kokalj et al. [13] considered that during the delithiation of $\mathrm{Li}_{2} \mathrm{MnSiO}_{4}$, phase separation of $\mathrm{Li}_{2} \mathrm{MnSiO}_{4}$ and $\mathrm{MnSiO}_{4}$ may occur. Because the latter is amorphous-like, amorphization can be observed upon the removal of small amounts of Li, which can explain the drop in the reversible capacity during cycling. The visible, stability of the material structure, in order to avoid structural collapse is a key factor in improving the material properties of $\mathrm{Li}_{2} \mathrm{MnSiO}_{4}$. Nyten et al. [14] studied $\mathrm{Li}_{2} \mathrm{MnSiO}_{4}$ using XRD refinement and found that in the process of charging and discharging, parts of $\mathrm{Mn}$ and $\mathrm{Li}$ are 
exchanged. Belharouak et al. [15] also reached a similar conclusion that the cationic mixing of $\mathrm{Li}^{+}$and $\mathrm{Mn}^{2+}$ ions at their mutual crystallographic sites is the main impediment to achieving the full theoretical capacity of $\mathrm{Li}_{2} \mathrm{MnSiO}_{4}$.

\section{Performance optimization method of silicate materials}

\subsection{Optimization of synthesis}

(1) Solid-state synthesis. Solid-state reactions are considered a traditional milling technology, though they are considered poorly efficient and are easy mixed with impurities, but due to the preparation process they are simple and inexpensive, so they are still commonly used to synthesize orthosilicate. $\mathrm{Li}_{2} \mathrm{FeSiO}_{4}$ was recently synthesized using the traditional solid-phase method described by Nyten et al. [2] for the first time. Ren et al. [16] prepared $\mathrm{Li}_{2} \mathrm{FeSiO}_{4}$ using solid-state reactions, and the particles of $\mathrm{Li}_{2} \mathrm{FeSiO}_{4}$ prepared using this method were evenly dispersed, demonstrating granularity between $300-400 \mathrm{~nm}$. When the cycling rate is $0.1 \mathrm{C}$ at room temperature, the first discharge capacity is $170 \mathrm{~mA} \mathrm{~h} \mathrm{~g}{ }^{-1}$. Xiang et al. [17] synthesized $\mathrm{Li}_{2} \mathrm{FeSiO}_{4}$ at different temperatures using solid-state reactions, and electrochemical tests showed that the first specific discharge capacity of $\mathrm{Li}_{2} \mathrm{FeSiO}_{4} / \mathrm{C}$ synthesized at $650^{\circ} \mathrm{C}$ was 144.8

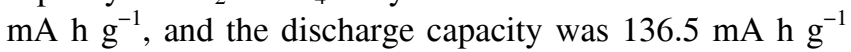
after 10 cycles. Nanoscale carbon-coated $\mathrm{Li}_{2} \mathrm{MnSiO}_{4}$ powder was prepared by Karthikeyan et al. [18] using the conventional solid-state method and the negative electrode of a $\mathrm{Li}_{2} \mathrm{MnSiO}_{4} /$ activated carbon (AC) hybrid super capacitor. The cell exhibits excellent cycle performance with $>99 \%$ columbic efficiency and maintains $85 \%$ of its initial capacitance after 1000 cycles. $\mathrm{Li}_{2} \mathrm{Fe}_{1-x} \mathrm{Mn}_{x} \mathrm{SiO}_{4} / \mathrm{C}$ cathode materials were synthesized by Guo et al. [19] using a mechanically activated solid-state reaction. Under optimal conditions $\left(650^{\circ} \mathrm{C}\right.$ calcined for $16 \mathrm{~h}, \mathrm{Li} / \mathrm{Si}$ ratio of 2.04) synthetic $\mathrm{Li}_{2} \mathrm{Fe}_{0.9} \mathrm{Mn}_{0.1} \mathrm{SiO}_{4} / \mathrm{C}$ demonstrated good electrochemical performance with an initial discharge capacity of $158.1 \mathrm{~mA} \mathrm{~h} \mathrm{~g}^{-1}$ and a capacity retention ratio of $94.3 \%$ after 30 cycles.

(2) Microwave synthesis. Compared with conventional heat synthesis, heat synthesis in a microwave field has the advantages of increased efficiency, integrity, selectivity and non-thermal effects, thus the microwave process demonstrates a faster response, higher efficiency, lower energy consumption and is more environmentally friendly and conducive to the formation of pure substances and fine grains. Muraliganth et al. [20] synthesized nanostructured $\mathrm{Li}_{2} \mathrm{FeSiO}_{4}$ and $\mathrm{Li}_{2} \mathrm{MnSiO}_{4}$ cathodes using facile microwave solvothermal synthesis. To improve crystallinity and enhance electronic conductivity, the resulting samples were mixed with sucrose and heated to $650^{\circ} \mathrm{C}$ for $6 \mathrm{~h}$ in an argon atmosphere. The $\mathrm{Li}_{2} \mathrm{FeSiO}_{4} / \mathrm{C}$ sample exhibits a high rate capability and stable cycle life, with discharge capacities of $148 \mathrm{~mA} \mathrm{~h} \mathrm{~g}^{-1}$ at room temperature and $204 \mathrm{~mA} \mathrm{~h} \mathrm{~g}^{-1}$ at $55^{\circ} \mathrm{C}$. Although $\mathrm{Li}_{2} \mathrm{MnSiO}_{4} / \mathrm{C}$ demonstrates higher discharge capacities of $210 \mathrm{~mA} \mathrm{~h} \mathrm{~g}^{-1}$ at room temperature and $250 \mathrm{~mA} \mathrm{~h} \mathrm{~g}^{-1}$ at $55^{\circ} \mathrm{C}$, it suffers from poor rate capability and drastic capacity fade. $\mathrm{A}_{2} \mathrm{FeSiO}_{4}$ cathode material was prepared by Peng et al. [21]. The highly pure product with a fine particle size and narrow size distribution was successfully obtained by mechanical ball-milling and microwave processing and the obtained sample demonstrates good electrochemical performance, cycling stability, and an initial discharge capacity of $116.9 \mathrm{~mA} \mathrm{~h} \mathrm{~g}^{-1}$ at $60^{\circ} \mathrm{C}$. Peng et al. [22] using super-P carbon as the microwave absorber powder, were able to quickly synthesize a $\mathrm{Li}_{2} \mathrm{FeSiO}_{4} / \mathrm{C}$ olivinephase material by microwave processing at $650^{\circ} \mathrm{C}$ for 10 min. The obtained material exhibited uniform and fine particle sizes and good electrochemical properties. The initial discharge capacity of the prepared $\mathrm{Li}_{2} \mathrm{FeSiO}_{4} / \mathrm{C}$ material is $121.7 \mathrm{~mA} \mathrm{~h} \mathrm{~g}^{-1}$ at $60^{\circ} \mathrm{C}$, after 10 cycles and the discharge capacity can be maintained at $119.2 \mathrm{~mA} \mathrm{~h} \mathrm{~g}^{-1}$.

(3) Hydrothermal synthesis. The characteristics of hydrothermal synthesis allow the production of high-quality particles with good dispersion and good crystals that are easily controlled with less thermal stress and fewer internal defects. The factors that impact hydrothermal synthesis include the temperature, heating speed, stirring speed, reaction time, etc. $\mathrm{Li}_{2} \mathrm{CoSiO}_{4}$ was prepared by Gong et al. [23] via hydrothermal reaction for the first time. Solid solutions with $\mathrm{Fe}$ and $\mathrm{Mn}$ cations in $\mathrm{Li}_{2} \mathrm{Fe}_{z} \mathrm{Mn}_{(1-z)} \mathrm{SiO}_{4}$ were successfully prepared by Dominko et al. [24] using hydrothermal synthesis. Three different synthesis techniques (hydrothermal synthesis, modified Pechini synthesis and Pechini synthesis) were successfully used to prepare $\mathrm{Li}_{2} \mathrm{FeSiO}_{4}$ samples by Dominko et al. [25]. The obtained samples demonstrate some differences in morphology and particle size, and fewer impurities were found in the samples that did not contain any in situ carbon that was prepared via hydrothermal synthesis. $\mathrm{Li}_{2} \mathrm{FeSiO}_{4} / \mathrm{C}$ composites contain the highest amounts of impurities (e.g. $\mathrm{Fe}_{2} \mathrm{O}_{3}, \mathrm{SiO}_{2}, \mathrm{Li}_{2} \mathrm{SiO}_{3}$ ) and only 68.8 at. $\%$ of $\mathrm{Fe}$ is in the form of $\mathrm{Fe}$ (II).

(4) Sol-gel synthesis. The sol-gel method uses compounds with highly chemically active precursors that are mixed together in the liquid phase under hydrolysis, thereby allowing condensation reactions to form a stable and transparent sol system. Sol, following the slow polymerization of colloidal particles, forms a 3-dimensional structural gel. After drying, sintering curing prepares the molecules and even the nanostructure materials. Using sol-gel, Du et al. [6] first synthesized $\mathrm{Li}_{2} \mathrm{MnSiO}_{4}$ materials. $\mathrm{Mg}_{1.03} \mathrm{Mn}_{0.97}-\mathrm{SiO}_{4}$ was prepared by Feng et al. [26] using a sol-gel method, which was then evaluated for use as an intercalation electrode material in rechargeable magnesium batteries. Using a ball mill in the presence of acetylene black, the resulting composites demonstrated an increased discharge specific capacity (92.9 $\mathrm{mA} \mathrm{h} \mathrm{g}^{-1}$ at $\left.\mathrm{C} / 50\right)$. An adipic acid-assisted sol-gel route was employed to prepare phase-pure $\mathrm{Li}_{2} \mathrm{MnSiO}_{4}$ under optimized conditions by Aravindan et al. [27]. The 
morphological features confirmed the appearance of evenly dispersed $\mathrm{Li}_{2} \mathrm{MnSiO}_{4}$ spherical nanoparticles with a size of approximately $30 \mathrm{~nm}$. The $\mathrm{Li} / \mathrm{Li}_{2} \mathrm{MnSiO}_{4}$ cell exhibited an initial discharge capacity of $161 \mathrm{~mA} \mathrm{~h} \mathrm{~g}^{-1}$ and delivered a stable discharge capacity profile of up to 50 cycles (125 $\left.\mathrm{mA} \mathrm{h} \mathrm{g}{ }^{-1}\right) . \mathrm{Li}_{2} \mathrm{MSiO}_{4} / \mathrm{C}$ composites $(\mathrm{M}=\mathrm{Mn}$ and/or $\mathrm{Fe}$ ) prepared by Dominko [28] via Pechini synthesis generally demonstrate large, $30-50 \mathrm{~nm}$ sized particles that are embedded in the carbon matrix, as shown in Figure 2. The amount of carbon in the composite is close to $10 \mathrm{wt} \%$ of the $\mathrm{Li}_{2} \mathrm{FeSiO}_{4} / \mathrm{C}$ composite and slightly $>5 \mathrm{wt} \%$ of the $\mathrm{Li}_{2} \mathrm{MnSiO}_{4} / \mathrm{C}$ composite.

(5) Supercritical solvothermal method. The supercritical solvothermal method allows the progression of hydrothermal reactions. One or more precursors is dissolved in a non aqueous solvent, under liquid or supercritical conditions, and the reactants are dispersed in solution and become active. Accordingly, the reactant (usually a solid) is dissolved, allowing the decentralization process and chemical reactivity to significantly improve or increase. This allows the reaction to occur at lower temperatures. As far as we know, during calcinations, particles might strongly aggregate, which affects the intrinsic conductivity of the cathode material and results in severe capacity fade. Materials prepared using this method demonstrate the advantages of uniform particle size, good dispersion and high crystallinity.

Kempaiah et al. [29] recently published a paper that describes monodispersed $\mathrm{Li}_{2} \mathrm{MnSiO}_{4}$ and PEDOT/Li $2 \mathrm{MnSiO}_{4}$ nanoparticles (PEDOT with a simple molecular structure, small energy gap, and high conductivity) that were synthe- sized using the supercritical solvothermal method at $300^{\circ} \mathrm{C}$ for $5 \mathrm{~min}$. The as-synthesized nanoparticles had a diameter of $15-20 \mathrm{~nm}$. Samples prepared using the present method demonstrate sevetal advantages over other methods, including good crystallinity at low temperatures; this includes the first synthesis of an almost $100 \%$ pure-phase $\mathrm{Li}_{2} \mathrm{MnSiO}_{4}$. The electrochemical performances of the PEDOT/ $\mathrm{Li}_{2} \mathrm{MnSiO}_{4}$ electrodes were compared with metallic $\mathrm{Li}$ in the presence of $\mathrm{LiClO}_{4}$ in EC and DMC at $0.05 \mathrm{C}$. PEDOT/ $\mathrm{Li}_{2} \mathrm{MnSiO}_{4}$ nanoparticles demonstrated remarkably high discharge capacities of 293 and $313 \mathrm{~mA} \mathrm{~h} \mathrm{~g}^{-1}$ at room temperature and at $40^{\circ} \mathrm{C}$, respectively, equal to the nearly $2.0 \mathrm{Li}$ extraction from the $\mathrm{Li}_{2} \mathrm{MnSiO}_{4}$ structure. In addition, the discharge capacity of $240 \mathrm{~mA} \mathrm{~h} \mathrm{~g}{ }^{-1}$ was retained after 20 cycles. The high discharge capacity is due to its high phase purity and monodispersed particles with $15 \mathrm{~nm}$ diameters that facilitate short reaction pathways for the Li insertion/ exertion process, which when coupled with high-conductive PEDOT material compounds, not only enhances the conductivity of the material, but also reduces irreversible changes in the structure, while avoiding the reunion of particles.

(6) Influence of the calcination temperature on materials. The calcining temperature plays a decisive role on the growth of the material's particle. The candidate cathode material $\mathrm{Li}_{2} \mathrm{MnSiO}_{4}$ for use in Li-ion cells was synthesized by Belharouak et al. [15] using an all-acetate precursor solgel method under a reducing atmosphere at 600, 700, and $800^{\circ} \mathrm{C}$, and the material prepared at $700^{\circ} \mathrm{C}$ was the purest. Scanning electron microscopy of $\mathrm{Li}_{2} \mathrm{MnSiO}_{4}$ showed
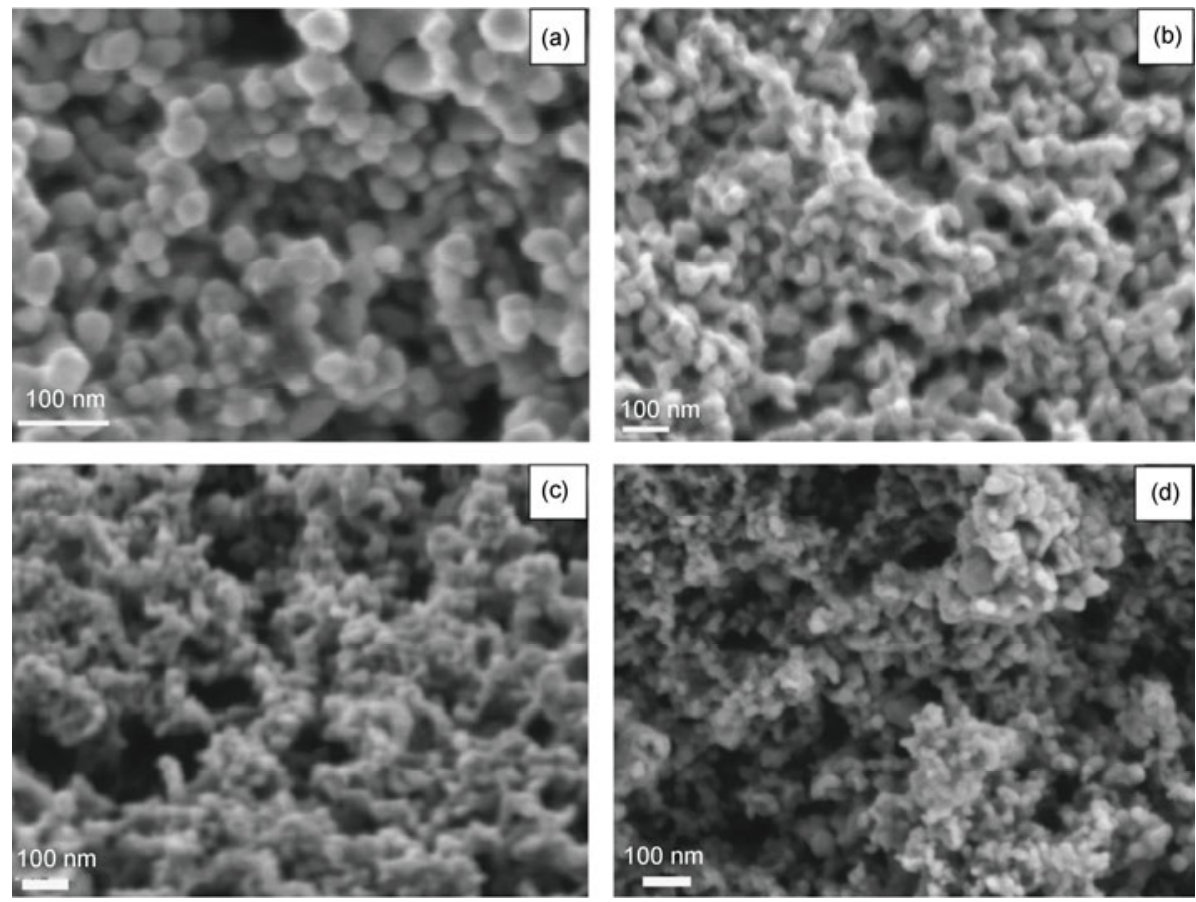

Figure 2 SEM micrographs of samples obtained using the Pechini method. (a) $\mathrm{Li}_{2} \mathrm{FeSiO}_{4} / \mathrm{C}$ composite; (b) $\mathrm{Li}_{2} \mathrm{Mn}_{0.25} \mathrm{Fe}_{0.75} \mathrm{SiO}_{4} / \mathrm{C}$ composite; (c) $\mathrm{Li}_{2} \mathrm{Mn}_{0.5} \mathrm{Fe}_{0.5} \mathrm{SiO}_{4} / \mathrm{C}$ composite; (d) $\mathrm{Li}_{2} \mathrm{MnSiO}_{4} / \mathrm{C}$ composite. Reprinted from [28] with permission from Elsevier. 
large aggregates $(10-50 \mu \mathrm{m})$ that were composed of nanosized particles (100-200 nm). Liu et al. [30] synthesized the $\mathrm{Li}_{2} \mathrm{MnSiO}_{4} / \mathrm{C}$ composite through a polyol process that was following by heat-treatment at temperature of 500, 600, $700^{\circ} \mathrm{C}$. The particle size increased from $5-20$ to $20-40 \mathrm{~nm}$ as the temperature increasing from 500 to $700^{\circ} \mathrm{C}$. Electrochemical experiments revealed that the sample that was treated at $600^{\circ} \mathrm{C}$ demonstrated the highest electrochemical performance with an initial discharge capacity of 132.4 $\mathrm{mA} \mathrm{h} \mathrm{g}{ }^{-1}$ and a capacity retention ratio of $80 \%$ during the tenth cycle. $\mathrm{Li}$ et al. [31] synthesized $\mathrm{Li}_{2} \mathrm{FeSiO}_{4} / \mathrm{C}$ cathodes by combining the wet-process method and the solid-state reaction. The primary particle size increases as the temperature increases from 600 to $750^{\circ} \mathrm{C}$. The $\mathrm{Li}_{2} \mathrm{FeSiO}_{4} / \mathrm{C}$ sample that was synthesized at $650^{\circ} \mathrm{C}$ demonstrates good electrochemical performances and an initial discharge capacity of $144.9 \mathrm{~mA} \mathrm{~h} \mathrm{~g}^{-1}$ and the discharge capacity remains at 136.5 $\mathrm{mA} \mathrm{h} \mathrm{g}$ after 10 cycles. Li et al. [32] reported that $\mathrm{Li}_{2} \mathrm{FeSiO}_{4}$ can be prepared via the solid-state reaction using $\mathrm{FeC}_{2} \mathrm{O}_{4} \cdot 2 \mathrm{H}_{2} \mathrm{O}$ and $\mathrm{Li}_{2} \mathrm{SiO}_{3}$, which can be synthesized using the sol-gel method at high temperatures. The calcination temperature plays an important role in the final properties of the $\mathrm{Li}_{2} \mathrm{SiO}_{3}$ samples. Samples calcined at $700^{\circ} \mathrm{C}$ provide $97 \%$ pure $\mathrm{Li}_{2} \mathrm{SiO}_{3}$ with good morphology that can be used as a precursor for the production of $\mathrm{Li}_{2} \mathrm{FeSiO}_{4}$. These samples consist of primary particles that are 1-3 $\mu \mathrm{m}$ in diameter, and the primary particle clusters form agglomerates with a loose and porous appearance. The effect of the sintering temperature on the performance of these materials was studied by Liu et al. [33]. $\mathrm{Li}_{2} \mathrm{MnSiO}_{4}$ materials synthesized via the traditional solid-state reaction, which are heated to $900^{\circ} \mathrm{C}$ for $20 \mathrm{~h}$ demonstrated the best initial specific discharge capacity $\left(118 \mathrm{~mA} \mathrm{~h} \mathrm{~g}^{-1}\right)$. Yang et al. [34] synthesized the $\mathrm{Li}_{2} \mathrm{MnSiO}_{4} / \mathrm{C}$ composite via the sol-gel method at temperatures of 500,600 and $700^{\circ} \mathrm{C}$. Electrochemical tests indicate that the $\mathrm{Li}_{2} \mathrm{MnSiO}_{4} / \mathrm{C}$ composite that was synthesized at $600^{\circ} \mathrm{C}$ for $10 \mathrm{~h}$ demonstrates the best electrochemical performance, including an initial discharge capacity of $124.2 \mathrm{~mA} \mathrm{~h} \mathrm{~g}^{-1}$, theoretical capacity of $74.5 \%$, and a discharge capacity of $71.5 \mathrm{~mA} \mathrm{~h} \mathrm{~g}^{-1}$ after 30 cycles.

\subsection{Carbon composites and coated materials}

Low electrical conductivity is one of the main problems that leads to the poor electrochemical performance of silicate materials, and the use of composite or coated materials with high conductivities could not only improve the overall conductivity of the whole composite, but also prevent the reunion of the particles, which would facilitate short reaction pathways for the insertion/exertion of Li. The application of materials with specific morphologies could enhance the structure of these materials, thus, improving the cycling performance.

(1) Selection of the carbon source. Moskon et al. [35] reported that the use of citrate precursors can provide pretty good conductivity (approximately $30 \mathrm{~S} \mathrm{~cm}^{-1}$ ) after a $10 \mathrm{~h}$ of heat treatment at $\geqslant 700^{\circ} \mathrm{C}$, while the conductivity plateau of the whole composite was observed at $0.1 \mathrm{~S} / \mathrm{cm}$. At that level, the carbon phase forms a well-distributed 3-dimensional electrical network within the composite. Li et al. [36] choose sucrose to prepare the $\mathrm{Li}_{2} \mathrm{MnSiO}_{4} / \mathrm{C}$ composite, resulting in crystalline $\mathrm{Li}_{2} \mathrm{MnSiO}_{4}$ particles that were surrounded by a very thin film of amorphous carbon. At a current density of $5 \mathrm{~mA} \mathrm{~g}^{-1}$, the material provides an initial discharge capacity of $209 \mathrm{~mA} \mathrm{~h} \mathrm{~g}^{-1}$, but attenuation was very serious, as shown in Figure 3, resulting in a discharge capacity being still low at a high ratio.

$\mathrm{Li}_{2} \mathrm{MnSiO}_{4}$ cathode powders were synthesized by Paromita et al. [7], and the as-synthesized powder was ballmilled with acetylene black (0-20 wt\%) to form the $\mathrm{Li}_{2} \mathrm{MnSiO}_{4} / \mathrm{C}$ composite. The addition of acetylene black resulted in drastic changes in the morphology of the $\mathrm{Li}_{2} \mathrm{MnSiO}_{4} / \mathrm{C}$ composites, which consisted of uniform grains that were approximately $50 \mathrm{~nm}$ in diameter. The electrochemical discharged capacity as well as the rate capability of $\mathrm{Li}_{2} \mathrm{MnSiO}_{4}$ also dramatically improved as the amount of conducting carbon (acetylene black) increased in the matrix, resulting in values as high as $164 \mathrm{~mA} \mathrm{~h} \mathrm{~g}^{-1}$ and a current density of $0.01 \mathrm{~mA} \mathrm{~cm}^{-2}$. Impedance spectroscopy showed that the addition of acetylene black decreases the charge-transfer impedance and balances the growth of cell impedance during cycling. $\mathrm{Li}_{2} \mathrm{MnSiO}_{4}$ was treated by carbon coating using a precursor to cellulose carbon by
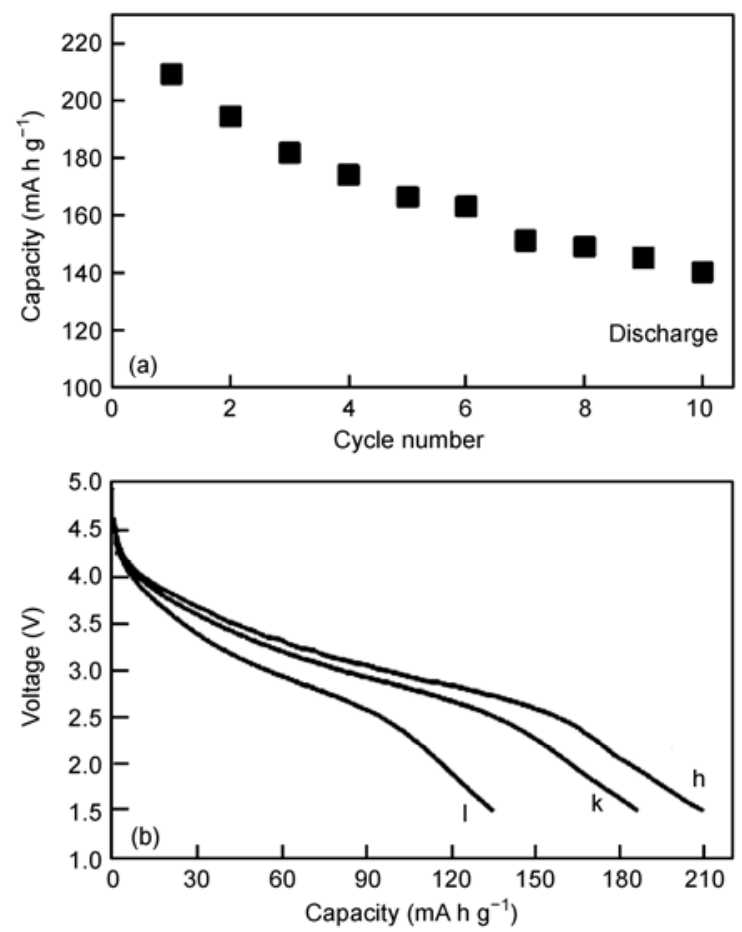

Figure 3 (a) Cycling performance of the material between $1.5-4.8 \mathrm{~V}$ at 5 $\mathrm{mA} \mathrm{g}^{-1}$. (b) First discharge curves at different current densities: h, $5 \mathrm{~mA} \mathrm{~g}{ }^{-1}$; $\mathrm{k}, 30 \mathrm{~mA} \mathrm{~g} \mathrm{~g}^{-1} ; 1,150 \mathrm{~mA} \mathrm{~g}^{-1}$. Reprinted from [36] with permission from Elsevier. 
Belharouak et al. [15], and the carbon-coated materials demonstrated a charge capacity of $190 \mathrm{~mA} \mathrm{~h} \mathrm{~g}^{-1}$. A $\mathrm{Li}_{2} \mathrm{MnSiO}_{4} / \mathrm{C}$ cathode material was synthesized by Liu et al. [37] using the traditional solid-state reaction method and sucrose as the carbon source. The product of $\mathrm{Li}_{2} \mathrm{MnSiO}_{4} / \mathrm{C}$ has a smaller particle size (approximately 30-80 nm), which is beneficial for $\mathrm{Li}$-extraction/insertion kinetics. The initial charge capacity of $\mathrm{Li}_{2} \mathrm{MnSiO}_{4} / \mathrm{C}$ is $256 \mathrm{~mA} \mathrm{~h} \mathrm{~g}^{-1}$ (about 1.5 $\mathrm{Li}^{+}$per unit formula extracted) or $129 \mathrm{~mA} \mathrm{~h} \mathrm{~g}^{-1}$ (about 0.77 $\mathrm{Li}^{+}$per unit formula), which can be reversibly exchanged during the first cycle at a rate of $\mathrm{C} / 16$. Ahn et al. [38] found that by applying nanocoated polyaniline nanodisks as the cathode material, the discharge capacity improved by about $15 \%$ and the cyclability was enhanced, reducing the continuous structural distortion that occurs during extended charge-discharge cycling. $\mathrm{Li}_{2} \mathrm{MnSiO}_{4}$ was synthesized by Aravindan et al. [39] via the solid-state reaction method using adipic acid as the source material for carbon. The $\mathrm{Li} / \mathrm{Li}_{2} \mathrm{MnSiO}_{4}$ cell delivered an initial discharge capacity of $160 \mathrm{~mA} \mathrm{~h} \mathrm{~g}^{-1}$ at $\mathrm{C} / 20$. After a few initial cycles, the cell exhibited stable discharge behavior of approximately 140

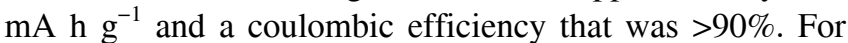
the first time, the $\mathrm{Li}_{2} \mathrm{MnSiO}_{4}$ electrode demonstrated stable discharge behavior.

(2) Influence of carbon content. The carbon content has significant influence on the properties of materials, and an increase in carbon can improve the conductivity of the material; however too much will increase the distance between the active substances, thereby blocking the transfer of $\mathrm{Li}$ ions. Aravindan et al. [40] used adipic acid as the carbon source, and the concentration varied during the synthesis process between $0-1.0 \mathrm{~mol}(0,0.05,0.1,0.2,0.5,1.0)$ against the total metal ions presents in $\mathrm{Li}_{2} \mathrm{MnSiO}_{4} ; 0.2 \mathrm{~mol}$ $(0.92 \mathrm{wt} \%)$ adipic acid produced the highest-performing material. Figure 4 illustrates how adipic acid was carbonized and formed as carbon at the surface, which prevents the growth of particles and enhances the electronic conductivity

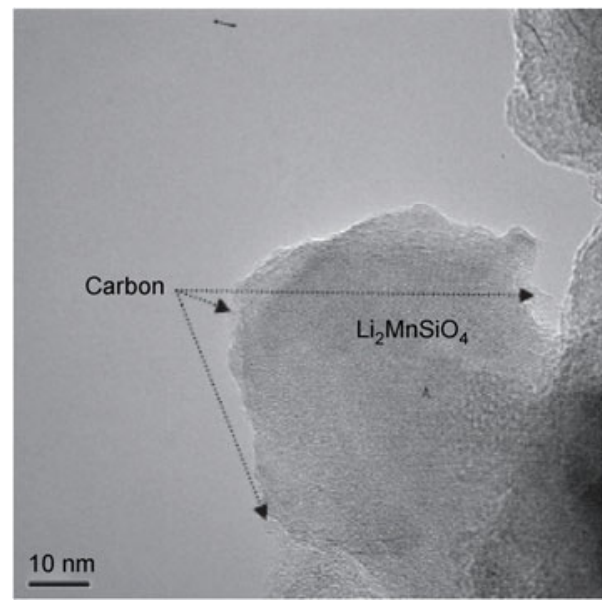

Figure 4 High resolution-transmission electron microscopic image of $\mathrm{Li}_{2} \mathrm{MnSiO}_{4}$ nanoparticles containing $0.2 \mathrm{~mol}$ adipic acid. Reprinted from [40] with permission from Elsevier. of the material. Using sucrose as the carbon source, a $\mathrm{Li}_{2} \mathrm{FeSiO}_{4} / \mathrm{C}$ composite was synthesized by Guo et al. [41], and the carbon content and the properties of the $\mathrm{Li}_{2} \mathrm{FeSiO}_{4} /$ $\mathrm{C}$ composites were investigated. As carbon content increases to the range of $5 \%-20 \%$, the amount of $\mathrm{Fe}_{3} \mathrm{O}_{4}$ impurities decreases. The $\mathrm{Li}_{2} \mathrm{FeSiO}_{4} / \mathrm{C}$ composite, which contains $14.5 \%$ carbon, demonstrates good electrochemical performance, an initial discharge capacity of $144.8 \mathrm{~mA} \mathrm{~h} \mathrm{~g}^{-1}$ and a capacity retention ratio of $94.27 \%$ after 13 cycles.

\subsection{Elemental substitution}

(1) Substitution of the $\mathrm{M}$ sites in $\mathrm{Li}_{2} \mathrm{MSiO}_{4}$. Metal doping is an efficiency way to improve the electrochemical performance of the cathode material in Li-ion batteries. $\mathrm{Li}_{2}\left(\mathrm{Fe}_{1-x^{-}}\right.$ $\left.\mathrm{Mn}_{x}\right) \mathrm{SiO}_{4}(x=0,0.3,0.5,0.7,1)$ cathode materials were synthesized by Deng et al. [42], as shown in Figure 5, and the prepared $\mathrm{Li}_{2}\left(\mathrm{Fe}_{1-x} \mathrm{Mn}_{x}\right) \mathrm{SiO}_{4}$ samples can all be indexed based on the orthorhombic unit cell in space group Pmn2 and their lattice parameters are similar. Nanoparticles have been observed in these samples. The maximum discharge capacity was obtained when $x=0.5$. However, the cycling performance of the $\mathrm{Li}_{2}\left(\mathrm{Fe}_{1-x} \mathrm{Mn}_{x}\right) \mathrm{SiO}_{4}$ samples decreases as $x$ increases. At the same time, Mn substitution lowers the electrochemical reversibility of the $\mathrm{Li}_{2}\left(\mathrm{Fe}_{1-x} \mathrm{Mn}_{x}\right) \mathrm{SiO}_{4}$ samples.

$\mathrm{Li}$ et al. [31] improved the performance of $\mathrm{Li}_{2} \mathrm{FeSiO}_{4} / \mathrm{C}$ by modifying $\mathrm{Ni}$ substitution. The $\mathrm{Li}_{2} \mathrm{Fe}_{0 .}{ }_{9} \mathrm{Ni}_{0.1} \mathrm{SiO}_{4} / \mathrm{C}$ composite cathode has an initial discharge capacity of 160.1 $\mathrm{mA} \mathrm{h} \mathrm{g}$, and the discharge capacity remains at 153.9 $\mathrm{mA} \mathrm{h} \mathrm{g}{ }^{-1}$ after 10 cycles. The diffusion coefficient of $\mathrm{Li}$ in $\mathrm{Li}_{2} \mathrm{FeSiO}_{4} / \mathrm{C}$ is $1.38 \times 10^{-12} \mathrm{~cm}^{2} \mathrm{~s}^{-1}$, while that of $\mathrm{Li}_{2} \mathrm{Fe}_{0.9^{-}}$ $\mathrm{Ni}_{0.1} \mathrm{SiO}_{4} / \mathrm{C}$ reaches $3.34 \times 10^{-12} \mathrm{~cm}^{2} \mathrm{~s}^{-1} . \mathrm{Li}_{2} \mathrm{Fe}_{0.97} \mathrm{Mg}_{0.03} \mathrm{SiO}_{4}$ was synthesized via the sol-gel method by Zhang et al. [43], and $\mathrm{Mg}^{2+}$ has been doped into the structure of $\mathrm{Li}_{2} \mathrm{FeSiO}_{4}$ without destroying its lattice structure. $\mathrm{Mg}$ doping improves the discharge capacity and cycle stability of $\mathrm{Li}_{2} \mathrm{FeSiO}_{4}$. Electrochemical impedance analysis shows that $\mathrm{Mg}$ doping decreases the charge-transfer resistance of $\mathrm{Li}_{2} \mathrm{FeSiO}_{4}$, and moreover, $\mathrm{Mg}$ doping increases the Li-ion diffusion

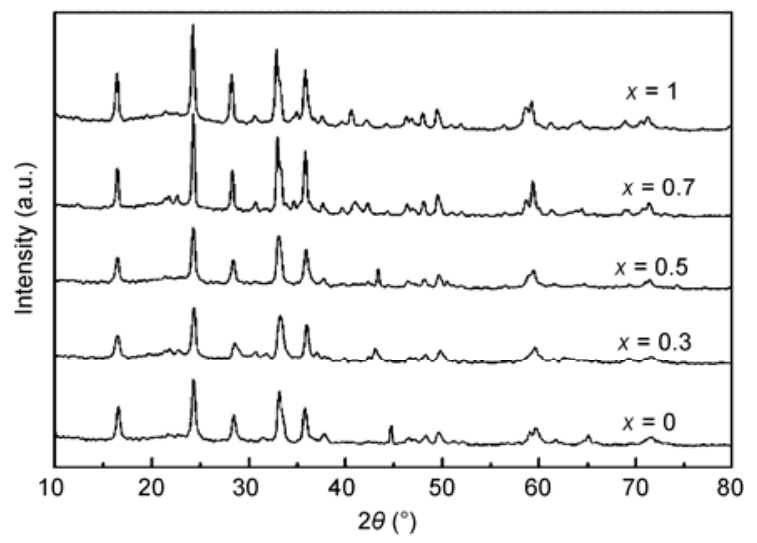

Figure 5 XRD patterns of the $\mathrm{Li}_{2}\left(\mathrm{Fe}_{1-x} \mathrm{Mn}_{x}\right) \mathrm{SiO}_{4}$ samples. Reprinted from [42] with permission from Elsevier. 
coefficient of $\mathrm{Li}_{2} \mathrm{FeSiO}_{4}$ by 1 order of magnitude. Cr-doped $\mathrm{Li}_{2} \mathrm{FeSiO}_{4}$ was prepared by Zhang et al. [44], who reported that the highest capacity that could be obtained by $\mathrm{Cr}$ doping was $3 \%$. The $\mathrm{Li}_{2} \mathrm{Fe}_{0.97} \mathrm{Cr}_{0.03} \mathrm{SiO}_{4}$ sample demonstrates faster activation, a higher reversible capacity, and a better rate capability, which could be attributed to the smaller particle size and larger surface area as well as the crystal defects that are induced by $\mathrm{Cr}$ doping. DFT calculations were presented by Larsson et al. [45], which desctibe the effects of low-concentration $\mathrm{Mn}$ substitution on the $\mathrm{Fe}$ sites in $\mathrm{Li}_{2} \mathrm{FeSiO}_{4}$. The $\mathrm{Li}_{x} \mathrm{Fe}_{0.875} \mathrm{Mn}_{0.125} \mathrm{SiO}_{4}$ system could be produced by replacing $12.5 \%$ of the Fe-sites in the $2 \times 2 \times 1$ and $2 \times 2 \times 2$ supercells with $\mathrm{Mn}$ ions. Clear structural distortions can be seen in the Mn-sites following delithiation, suggesting possible structural instabilities that increases capacity in $\mathrm{Li}_{2} \mathrm{Fe}_{1-y} \mathrm{Mn}_{y} \mathrm{SiO}_{4}$ through $>1$ electron redox reactions, though this may not be readily attainable in practice. Attempts to dope $\mathrm{Zn}^{2+}, \mathrm{Cu}^{2+}, \mathrm{Ni}^{2+}$ into $\mathrm{Li}_{2} \mathrm{FeSiO}_{4}$ were attempted by Deng et al. [46]. The discharge capacity of the $\mathrm{Zn}$-doped sample was $3.9 \%$ higher than that of the undoped sample, and the $\mathrm{Zn}$-doped sample demonstrated the highest cycling stability; however, $\mathrm{Ni}^{2+}$ and $\mathrm{Cu}^{2+}$ cannot be doped into the lattice of $\mathrm{Li}_{2} \mathrm{FeSiO}_{4}$. An $\mathrm{Li}_{2} \mathrm{Al}_{0.1} \mathrm{Mn}_{0.9} \mathrm{SiO}_{4}$ cathode material was synthesized by Liu et al. [47], but a small amount of impurities was present. The particle size of the $\mathrm{Li}_{2} \mathrm{Al}_{0.1} \mathrm{Mn}_{0.9} \mathrm{SiO}_{4}$ sample was $100-500 \mathrm{~nm}$ and the morphology of the particle shape was not spherical. The reversible capacity and cycle life of the cathode sample improved with $\mathrm{Al}$ doping, and the mechanism illustrates that Al doping can stabilize the microstructure of the $\mathrm{Li}_{2} \mathrm{MnSiO}_{4}$ cathode material. Liu et al. [48] also synthesized $\mathrm{Li}_{2} \mathrm{Ti}_{0.1^{-}}$ $\mathrm{Mn}_{0.9} \mathrm{SiO}_{4}$, which was similar to $\mathrm{Li}_{2} \mathrm{Al}_{0.1} \mathrm{Mn}_{0.9} \mathrm{SiO}_{4}$. The multicomponent olivine cathode material, $\mathrm{LiMn}_{1 / 3} \mathrm{Fe}_{1 / 3}$ $\mathrm{Co}_{1 / 3} \mathrm{PO} 4$, was prepared by Park et al. [49] via a novel coprecipitation method that used a mixed transition-metal oxalate. The electrochemical activity of each transition metal in olivine that was synthesized via this method was clearly enhanced. Three distinctive contributions from $\mathrm{Mn}, \mathrm{Fe}$, and Co redox couples were reversibly detected in multiple charge/discharge processes. In the later experimental doping studies, substitution of the M sites in the orthosilicate material can be performed using materials other than metal ions, resulting in the performance of different ion synergies to improve the electrochemical properties of the material.

(2) Substitution of the $\mathrm{O}$ sites in $\mathrm{Li}_{2} \mathrm{MSiO}_{4}$. First principles calculations were used to anticipate the electrochemistry of polyoxoanionic materials consisting of $\mathrm{XO}_{4-y} \mathrm{~A}_{y}(\mathrm{~A}=$ F, N) groups by Armand et al. [50]. For example, this work focused on the effects of $\mathrm{N}$ and $\mathrm{F}$ on $\mathrm{O}$ substitution and the electrochemical properties of $\mathrm{Li}_{2} \mathrm{FeSiO}_{4}$. Within the $P m n 2_{1^{-}}$ $\mathrm{Li}_{2} \mathrm{FeSiO}_{4}$ structure, virtual models of $\mathrm{Li}_{2} \mathrm{Fe}_{2}{ }^{2.5+} \mathrm{SiO}_{3.5} \mathrm{~N}_{0.5}$ and $\mathrm{Li}_{1.5} \mathrm{Fe}^{2+} \mathrm{SiO}_{3.5} \mathrm{~F}_{0.5}$ were analyzed. They predicted that the $\mathrm{Li}$ deinsertion voltage is associated with $\mathrm{Fe}^{3+} / \mathrm{Fe}^{4+}$ redox coupling, which was decreased by both substituents. $\mathrm{Li}_{1.5} \mathrm{Fe}^{2+} \mathrm{SiO}_{3.5} \mathrm{~F}_{0.5}$ demonstrates a lower specific capacity than is inherent to F substitution. Substitution of N/F for $\mathrm{O}$ will respectively improve/worsen the electrode characteristics of $\mathrm{Li}_{2} \mathrm{FeSiO}_{4}$. Armand and Arroyo-de Dompablo [51] further investigated the effect of $\mathrm{N}$ for $\mathrm{O}$ substitution on the electrochemical properties of $\mathrm{Li}_{2} \mathrm{FeSiO}_{4}$. Within the $\mathrm{Li}_{2} \mathrm{FeSiO}_{4}$ structure, hypothetical models of $\mathrm{N}$-substituted $\mathrm{Li}_{2} \mathrm{FeSiO}_{3} \mathrm{~N}$ and $\mathrm{Li}_{2} \mathrm{FeSiO}_{3.5} \mathrm{~N}_{0.5}$ were analyzed. The computational results indicate that the lithium deinsertion voltage associated with $\mathrm{Fe}^{3+} / \mathrm{Fe}^{4+}$ redox coupling could be decreased by $\mathrm{N}$ substitution $\left(4.86 \mathrm{~V}\right.$ in $\mathrm{Li}_{2} \mathrm{FeSiO}_{4}, 4.7 \mathrm{~V}$ in $\mathrm{Li}_{2} \mathrm{FeSiO}_{3.5} \mathrm{~N}_{0.5}$ and $4.1 \mathrm{~V}$ in $\left.\mathrm{Li}_{2} \mathrm{FeSiO}_{3} \mathrm{~N}\right)$. The high theoretical specific capacity of $\mathrm{Li}_{2} \mathrm{FeSiO}_{4}\left(330 \mathrm{~mA} \mathrm{~h} \mathrm{~g}{ }^{-1}\right)$ could be retained in $\mathrm{N}$-substituted silicates due to the oxidation of $\mathrm{N}^{3-}$ anions. In light of the potential benefits of $\mathrm{N}$ substitution for $\mathrm{O}$, experimental research is encouraged, in particular studies that investigate the reversibility and overpotential of the $\mathrm{N}$ redox reaction.

(3) Substitution of the $\mathrm{Si}$ sites in $\mathrm{Li}_{2} \mathrm{MSiO}_{4}$. Defect chemistry, doping behavior, and Li-diffusion paths in $\mathrm{Li}_{2} \mathrm{MnSiO}_{4}$ were investigated using advanced modeling techniques. Kuganathan and Islam [52] found that the most favorable dopant incorporation was for $\mathrm{Al}^{3+}$ at the $\mathrm{Si}$ site in the monoclinic structure with $\mathrm{Li}$ interstitial compensation. $\mathrm{Li} / \mathrm{Mn}$ anti-site defects or cation exchange can be improved by introducing extra $\mathrm{Li}$ in order to form the $\mathrm{Li}_{2+x} \mathrm{MnSi}_{1-x^{-}}$ $\mathrm{Al}_{x} \mathrm{O}_{4}$ system, although the exact amount of $\mathrm{Al}$ that is incorporated cannot be predicted. Of course, the ideal scenario would be $x=1.0$ for a solid solution consisting of $\mathrm{Li}_{2+x^{-}}$ $\mathrm{MnSi}_{1-x} \mathrm{Al}_{x} \mathrm{O}_{4}$, which permits the removal of two $\mathrm{Li}^{+}$from the structure when accompanied by the oxidation of $\mathrm{Mn}^{2+}$ to $\mathrm{Mn}^{4+}$, thereby yielding a high capacity for storing charge (approximately $300 \mathrm{~mA} \mathrm{~h} \mathrm{~g}^{-1}$ ).

(4) Substitution of the $\mathrm{Li}$ sites in $\mathrm{Li}_{2} \mathrm{MSiO}_{4}$. Na-substituted dilithium orthosilicate $\mathrm{Li}_{2} \mathrm{CoSiO}_{4}$ was investigated by performing density-function theoretical calculations within the GGA+U framework. The effects of Na-substitution on the electronic structures and structural properties of $\mathrm{Li}_{2} \mathrm{CoSiO}_{4}$ were presented by $\mathrm{Wu}$ et al. [53]. The results showed that Na-substitution at the $\mathrm{Li}$ sites in $\mathrm{Li}_{2} \mathrm{CoSiO}_{4}$ lowers the conduction bands and narrows the band gaps, which could enhance electrical conductivity. On the other hand, the Na-substitution of the $\mathrm{Li}$ ions in $\mathrm{Li}_{2} \mathrm{CoSiO}_{4}$ could lead to the expansion of the interlayer spaces within the adjacent corrugated layers. This lattice-expansion effect would benefit Li-ion diffusion.

\subsection{Porous materials}

A porous $\mathrm{Li}_{2} \mathrm{FeSiO}_{4} / \mathrm{C}$ composite was synthesized by Fan et al. [54]. The $\mathrm{Li}_{2} \mathrm{FeSiO}_{4} / \mathrm{C}$ composite is characterized by a large amount of particles that are approximately $5 \mu \mathrm{m}$ in size. These particles are composed of a large number of smaller crystal grains that are approximately $100 \mathrm{~nm}$, which are combined in many irregular pores. This structure not only offers channels for the infiltration of liquid electrolytes, 
but also avoids the aggregation of nanoparticles during synthesis and/or electrochemical cycling. Although the $\mathrm{Li}_{2} \mathrm{FeSiO}_{4} / \mathrm{C}$ cathode demonstrates a lower initial discharge capacity of $134 \mathrm{~mA} \mathrm{~h} \mathrm{~g}^{-1}$, this improves to $155 \mathrm{~mA} \mathrm{~h} \mathrm{~g}^{-1}$ after 190 electrochemical cycles, as shown in Figure 6. Nanoembossed mesoporous $\mathrm{LiFePO}_{4}$ microspheres were first synthesized by Qian et al. [55] using a template-free hydrothermal process. These microspheres demonstrate a uniform size distribution of approximately $3 \mu \mathrm{m}$ and are composed of many densely aggregated $100 \mathrm{~nm}$ nanoparticles and interconnected nanochannels. This mesoporous structure allows sucrose to easily penetrate into the spheres and generate a thorough carbon coating on the surfaces of the nanoparticles on the interior of the spheres. These microspheres as a cathode-active material demonstrate a high tap density $\left(1.4 \mathrm{~g} \mathrm{~cm}^{-3}\right)$, excellent rate capability (115 $\mathrm{mA} \mathrm{h} \mathrm{g}{ }^{-1}, 10 \mathrm{C}$ ), and cycle stability.

Mesoporous magnesium manganese silicate as a cathode material used in rechargeable Mg batteries, was prepared by Nuly et al. [56] using mesoporous silica MCM-41 as both the template and silicon source. The mesoporous material exhibits better electrochemical performance with lower polarization for $\mathrm{Mg}$ de-intercalation and intercalation, larger discharge capacity and higher discharge flat plateau compared with the corresponding bulk material. At $0.2 \mathrm{C}$, the initial discharge capacity and discharge voltage plateau of the mesoporous material can reach $241.8 \mathrm{~mA} \mathrm{~h} \mathrm{~g}^{-1}$ and 1.65 $\mathrm{V}$, respectively. The larger surface area of the mesoporous material favors efficient contact between the active material and the electrolyte, thereby providing additional active sites for electrochemical reactions, that are conducive to the transfer of the Li-ions, and for protecting the structure of the material during the processes of charging and discharging. This mesoporous structure may provide new approaches that could improve the reaction activity of the cathode materials used in rechargeable $\mathrm{Mg}$ batteries.

\section{Summary and prospects}

Poly anionic silicate materials that demonstrate high theoretical capacities, high levels of security, environmental friendliness and low cost attract the attention of many researchers, but this type of material was developed relatively recently and is relatively rare. The structures and properties of this material are still uncertain, and it is difficult to synthesize high-purity materials. Therefore the focus of future research should include in-depth studies of this material in order to clearly understand its structure, determine the mechanisms of capacity fade, optimize its synthesis, determine the best conditions for the synthesis of pure orthosilicate materials, improve the material's charge and discharge
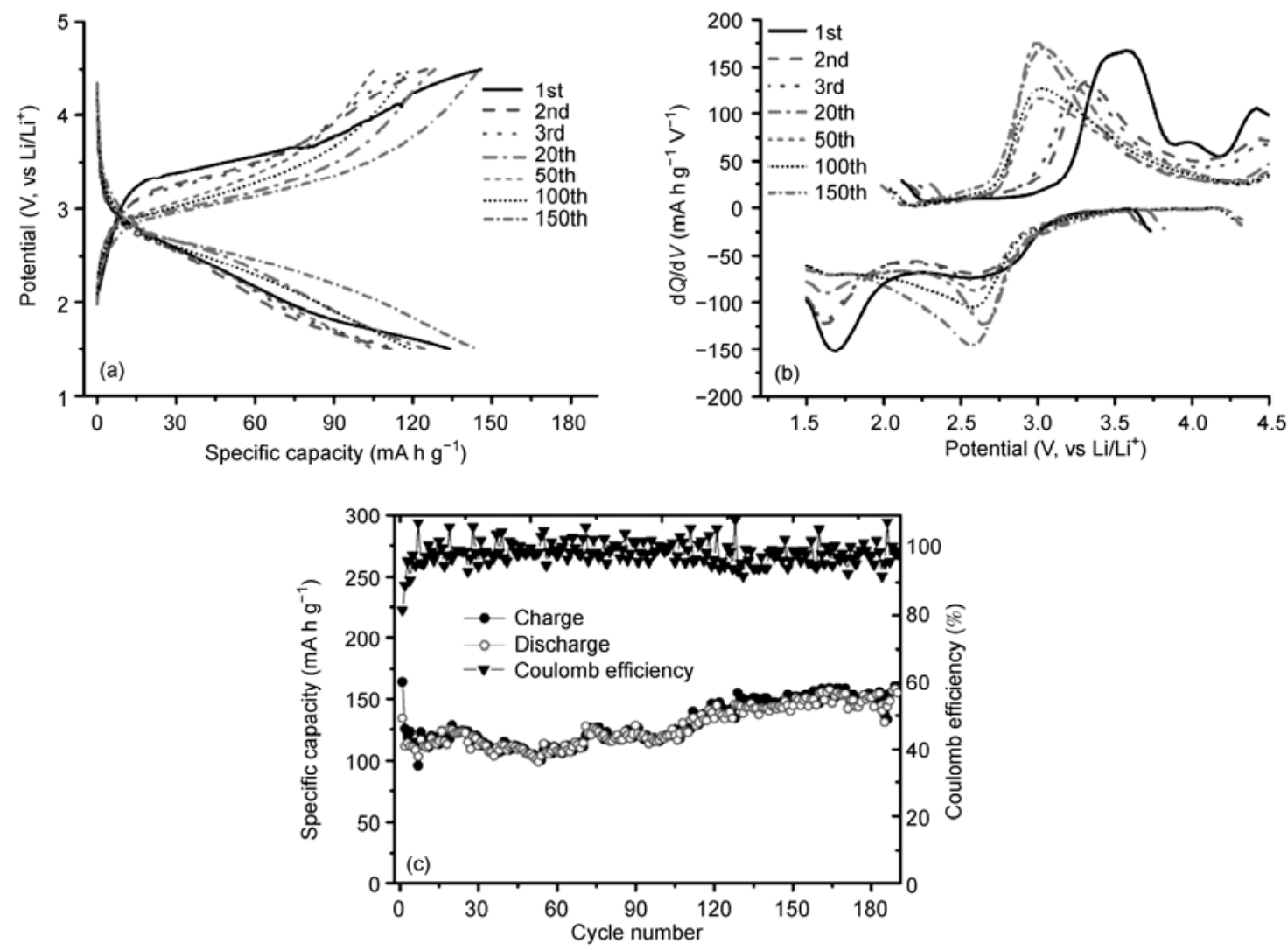

Figure 6 (a) Charge/discharge, (b) differential capacity, and (c) cycleability curves of $\mathrm{Li}_{2} \mathrm{FeSiO}_{4} / \mathrm{C}$ composite. Reprinted from [54] with permission from Elsevier. 
capacity and cycling performance (e.g. reduce the material's particle size, improve metal doping techniques, and elucidate its special morphology), and improve its low conductivity, such as by seeking suitable carbon sources and by optimizing carbon coating and composite conditions.

This work was supported by the National Basic Research Program of China (2009CB220100), the National Natural Science Foundation of China (51102018 and 21103011) and the National High-Tech R\&D Program of China (2011AA11A235 and SQ2010AA1123116001).

1 Arroyo-de Dompablo M E, Armand M, Tarascon J M, et al. Ondemand design of polyoxianionic cathode materials based on electronegativity correlations: An exploration of the $\mathrm{Li}_{2} \mathrm{MSiO}_{4}$ system (M $=\mathrm{Fe}, \mathrm{Mn}, \mathrm{Co}, \mathrm{Ni})$. Electrochem Commun, 2006, 8: 1292-1298

2 Nyten A, Abouimrane A, Armand M, et al. Electrochemical performance of $\mathrm{Li}_{2} \mathrm{FeSiO}_{4}$ as a new Li-battery cathode material. Electrochem Commun, 2005, 7: 156-160

3 Dominko R, Bele M, Gaberscek M, et al. Structure and electrochemical performance of $\mathrm{Li}_{2} \mathrm{MnSiO}_{4}$ and $\mathrm{Li}_{2} \mathrm{FeSiO}_{4}$ as potential Li-battery cathode materials. Electrochem Commun, 2006, 8: 217-222

4 Deng C, Zhang S, Gao Y, et al. Regeneration and characterization of air-exposed $\mathrm{Li}_{2} \mathrm{FeSiO}_{4}$. Electrochim Acta, 2011, 56: 7327-7333

5 Ma Y R, Sun S R, Zhang L J, et al. Progress in lithium-ion battery cathode material (in Chinese). Adv Mater Ind, 2009, 3: 10-14

$6 \mathrm{Du} \mathrm{K}, \mathrm{Hu} \mathrm{G} \mathrm{R}$. Review of manganese-based solid solution $x \mathrm{Li}\left[\mathrm{Li}_{1 / 3^{-}}\right.$ $\left.\mathrm{Mn}_{2 / 3}\right] \mathrm{O}_{2}(1-x) \mathrm{LiMO}_{2}$ (in Chinese). Chin Sci Bull (Chin Ver), 2012, 57: 794-804

7 Paromita G, Mahanty S, Basu R N. Improved electrochemical performance of $\mathrm{Li}_{2} \mathrm{MnSiO}_{4} / \mathrm{C}$ composite synthesized by combustion technique. J Electrochem Soc, 2009, 156: A677-A681

8 Politaev V V, Petrenko A A, Nalbandyan V B, et al. Crystal structure, phase relations and electrochemical properties of monoclinic $\mathrm{Li}_{2} \mathrm{MnSiO}_{4}$. J Solid State Chem, 2007, 180: 1045-1050

9 Arroyoy de Dompablo M E, Dominko R, Gallardo-Amores J M, et al. On the energetic stability and electrochemistry of $\mathrm{Li}_{2} \mathrm{MnSiO}_{4}$ polymorphs. Chem Mater, 2008, 20: 5574-5584

10 Arroyoy de Dompablo M E, Amador U, Gallardo-Amores J M, et al. Polymorphs of $\mathrm{Li}_{3} \mathrm{PO}_{4}$ and $\mathrm{Li}_{2} \mathrm{MSiO}_{4}(\mathrm{M}=\mathrm{Mn}, \mathrm{Co})$ the role of pressure. J Power Sources, 2009, 189: 638-642

11 Dominko R, Arcon I, Kodre A, et al. In-situ XAS study on $\mathrm{Li}_{2} \mathrm{MnSiO}_{4}$ and $\mathrm{Li}_{2} \mathrm{FeSiO}_{4}$ cathode materials. J Power Sources, 2009, 189: 51-58

12 Dominko R, Bele M, Kokalj A, et al. $\mathrm{Li}_{2} \mathrm{MnSiO}_{4}$ as a potential Libattery cathode material. J Power Sources, 2007, 174: 457-461

13 Kokalj A, Dominko R, Mali G, et al. Beyond one-electron reaction in Li cathode materials: Designing $\mathrm{Li}_{2} \mathrm{Mn}_{x} \mathrm{Fe}_{1-x} \mathrm{SiO}_{4}$. Chem Mater, 2007, 19: $3633-3640$

14 Nyten A, Saeed K, Lennart H, et al. The lithium extraction/insertion mechanism in $\mathrm{Li}_{2} \mathrm{FeSiO}_{4}$. Mater Chem, 2006, 16: 2266-2272

15 Belharouak I, Abouimrance A, Amine K. Structural and electrochemical characterization of $\mathrm{Li}_{2} \mathrm{MnSiO}_{4}$ cathode material. J Phys Chem, 2009, 113: 20733-20737

16 Ren B, Xu Y H, Yang R, et al. Preparation of $\mathrm{Li}_{2} \mathrm{FeSiO}_{4}$ as cathode materials for lithium-ion battery by solid-state reaction (in Chinese). Mater Heat Treatment, 2009, 38: 41-43

17 Xiang K X, Guo H J, Li X H, et al. Effect of synthesis temperature on the electrochemical performance of $\mathrm{Li}_{2} \mathrm{FeSiO}_{4} / \mathrm{C}$ (in Chinese). Functional Mater, 2008, 9: 1455-1457

18 Karthikeyan K, Aravindan V, Lee S B, et al. Electrochemical performance of carbon-coated lithium manganese silicate for asymmetric hybrid supercapacitors. J Power Sources, 2010, 195: 3761-3764

19 Guo H, Cao X, Li X, et al. Optimum synthesis of $\mathrm{Li}_{2} \mathrm{Fe}_{1-x} \mathrm{Mn}_{x} \mathrm{SiO}_{4} / \mathrm{C}$ cathode for lithium ion batteries. Electrochim Acta, 2010, 55: 80368042

20 Muraliganth T, Stroukoff K R, Manthiram A. Microwave-solvothermal synthesis of nanostructured $\mathrm{Li}_{2} \mathrm{MSiO}_{4} / \mathrm{C}(\mathrm{M}=\mathrm{Mn}$ and $\mathrm{Fe})$ cathodes for lithium-ion batteries. Chem Mater, 2010, 22: 5754-5761

21 Peng Z D, Cao Y B, Hu G R, et al. Preparation of $\mathrm{Li}_{2} \mathrm{FeSiO}_{4}$ cathode material for lithium-ion batteries by microwave synthesis. Chin Chem Lett, 2009, 20: 1000-1004

22 Peng Z D, Cao Y B, Hu G R, et al. Microwave synthesis of $\mathrm{Li}_{2} \mathrm{FeSiO}_{4} / \mathrm{C}$ cathode materials for lithium ion battery (in Chinese). Chin J Nonferrous Metals, 2009, 19: 1450-1454

23 Gong Z L, Li Y X, Yang Y. Synthesis and electrochemical performance of $\mathrm{Li}_{2} \mathrm{CoSiO}_{4}$ as cathode material for lithium ion batteries. $\mathrm{J}$ Power Sources, 2007, 174: 524-527

24 Dominko R, Sirisopanaporn C, Masquelier C, et al. On the origin of the electrochemical capacity of $\mathrm{Li}_{2} \mathrm{Fe}_{0.8} \mathrm{Mn}_{0.2} \mathrm{SiO}_{4}$. J Electrochem Soc, 2010, 157: A1309-A1316

25 Dominko R, Conte D E, Hanzel D, et al. Impact of synthesis conditions on the structure and performance of $\mathrm{Li}_{2} \mathrm{FeSiO}_{4}$. J Power Sources, 2008, 178: 842-847

26 Feng $\mathrm{Z} \mathrm{Z}$, Yang J, Li Y N, et al. Sol-gel synthesis of $\mathrm{Mg}_{1.03^{-}}$ $\mathrm{Mn}_{0.97} \mathrm{SiO}_{4}$ and its electrochemical intercalation behavior. J Power Sources, 2008, 184: 604-609

27 Aravindan V, Karthikeyan K, Ravib S, et al. Adipic acid assisted solgel synthesis of $\mathrm{Li}_{2} \mathrm{MnSiO}_{4}$ nanoparticles with improved lithium storage properties. J Mater Chem, 2010, 20: 7340-7343

28 Dominko R. $\mathrm{Li}_{2} \mathrm{MSiO}_{4}(\mathrm{M}=\mathrm{Fe}$ and/or $\mathrm{Mn})$ cathode materials. J Power Sources, 2008, 184: 462-468

29 Kempaiah D M, Rangappa D, Honma I. Controlled synthesis of nanocrystalline $\mathrm{Li}_{2} \mathrm{MnSiO}_{4}$ particles for high capacity cathode application in lithium-ion batteries. Chem Commun, 2012, 48: 2698-2700

30 Liu W G, Xu Y H, Yang R, et al. Effect of heat-treatment temperature on the electrochem ical performances of the $\mathrm{Li}_{2} \mathrm{MnSiO}_{4} / \mathrm{C}$ composite prepared through polyol process. J Inorg Mater, 2010, 25: 328-331

31 Li L M, Guo H J, Li X H, et al. Effects of roasting temperature and modification on properties of $\mathrm{Li}_{2} \mathrm{FeSiO}_{4} / \mathrm{C}$ cathode. J Power Sources, 2009, 189: 45-50

32 Li X Q, Guo H J, Li L M, et al. Effects of calcination temperature on properties of $\mathrm{Li}_{2} \mathrm{SiO}_{3}$ for precursor of $\mathrm{Li}_{2} \mathrm{FeSiO}_{4}$. Trans Nonferrous Met Soc China, 2011, 21: 529-534

33 Liu W G, Xu Y H, Zhou Z B, et al. Effects of synthesis conditions on performance of $\mathrm{Li}_{2} \mathrm{MnSiO}_{4}$ as cathode material (in Chinese). Chin $\mathrm{J}$ Power Sources, 2010, 4: 360-362

34 Yang Y, Fang H S, Li L P, et al. Synthesis and electrochemical performance of $\mathrm{Li}_{2} \mathrm{MnSiO}_{4} / \mathrm{C}$ composite cathode materials (in Chinese). Rare Metal Mater Eng, 2008, 6: 1086-1088

35 Moskon J, Dominko R, Cerc-Korosec R, et al. Morphology and electrical properties of conductive carbon coatings for cathode materials. J Power Sources, 2007, 174: 683-688

36 Li Y X, Gong Z L, Yang Y, et al. Synthesis and characterization of $\mathrm{Li}_{2} \mathrm{MnSiO}_{4} / \mathrm{C}$ nano composite cathode material for lithium ion batteries. J Power Sources, 2007, 174: 528-532

37 Liu W G, Xu Y H, Yang R. Synthesis characterization and electrochemical performance of $\mathrm{Li}_{2} \mathrm{MnSiO}_{4} / \mathrm{C}$ cathode material by solidstate reaction. J Alloys Compd, 2009, 480: L1-L4

38 Ahn D, Koo Y M, Kim M G, et al. Polyaniline nanocoating on the surface of layered $\mathrm{Li}\left[\mathrm{Li}_{0.2} \mathrm{Co}_{0.1} \mathrm{Mn}_{0.7}\right] \mathrm{O}_{2}$ nanodisks and enhanced cyclability as a cathode electrode for rechargeable lithium-ion battery. J Phys Chem C, 2010, 114: 3675-3680

39 Aravindan V, Karthikeyan K, Amaresh S, et al. Superior lithium storage properties of carbon coated $\mathrm{Li}_{2} \mathrm{MnSiO}_{4}$ cathodes. Electrochem Solid-State Lett, 2011, 14: A33-A35

40 Aravindan V, Ravi S, Kim W S, et al. Size controlled synthesis of $\mathrm{Li}_{2} \mathrm{MnSiO}_{4}$ nanoparticles: Effect of calcinations temperature and carbon content for high performance lithium batteries. J Colloid Interface Sci, 2011, 355: 472-477

41 Guo H J, Xiang K X, Cao X, et al. Preparation and characteristics of $\mathrm{Li}_{2} \mathrm{FeSiO}_{4} / \mathrm{C}$ composite for cathode of lithium ion batteries. Trans Nonferrous Met Soc China, 2009, 19: 166-169

42 Deng C, Zhang S, Yang S Y. Effect of Mn substitution on the structural, morphological and electrochemical behaviors of $\mathrm{Li}_{2} \mathrm{Fe}_{1-x^{-}}$ $\mathrm{Mn}_{x} \mathrm{SiO}_{4}$ synthesized via citric acid assisted sol-gel method. J Alloys 
Compd, 2009, 487: L18-L23

43 Zhang S, Deng C, Fu B L, et al. Doping effects of magnesium on the electrochemical performance of $\mathrm{Li}_{2} \mathrm{FeSiO}_{4}$ for lithium ion batteries. $\mathrm{J}$ Electroanal Chem, 2010, 644: 150-154

44 Zhang S, Deng C, Fu B L, et al. Effects of Cr doping on the electrochemical properties of $\mathrm{Li}_{2} \mathrm{FeSiO}_{4}$ cathode material for lithium-ion batteries. Electrochim Acta, 2010, 55: 8482-8489

45 Larsson P, Ahuja R, Liivat A, et al. Structural and electrochemical aspects of Mn substitution into $\mathrm{Li}_{2} \mathrm{FeSiO}_{4}$ from DFT calculations. Comput Mater Sci, 2010, 47: 678-684

46 Deng C, Zhang S, Yang S Y, et al. Synthesis and characterization of $\mathrm{Li}_{2} \mathrm{Fe}_{0.97} \mathrm{M}_{0.03} \mathrm{SiO}_{4}\left(\mathrm{M}=\mathrm{Zn}^{2+}, \mathrm{Cu}^{2+}, \mathrm{Ni}^{2+}\right)$ cathode materials for lithium ion batteries. J Power Sources, 2011, 196: 386-392

47 Liu W G, Xu Y H, Yang R, et al. Preparation and electrochemical performance of Al-doped $\mathrm{Li}_{2} \mathrm{MnSiO}_{4}$ cathode material for lithium ion batteries (in Chinese). Mater Heat Treatment, 2010, 2: 21-26

48 Liu W G, Xu Y H, Yang R, et al. Preparation and performance of $\mathrm{Li}_{2} \mathrm{Mn}_{0.9} \mathrm{Ti}_{0.1} \mathrm{SiO}_{4}$ cathode material for lithium ion batteries (in Chinese). Mater Heat Treatment, 2009, 16: 25-28

49 Park Y U, Kim J, Gwon H, et al. Synthesis of multicomponent olivine by a novel mixed transition metal oxalate coprecipitation method and electrochemical characterization. Chem Mater, 2010, 22: 2573-2581
50 Armand M, Tarascon J M, Arroyo-de Dompablo M E. Comparative computational investigation of $\mathrm{N}$ and $\mathrm{F}$ substituted polyoxoanionic compounds. Electrochem Commun, 2011, 13: 1047-1050

51 Armand M, Arroyo-de Dompablo M E. Benefits of N for O substitution in polyoxoanionic electrode materials: A first principles investigation of the electrochemical properties of $\mathrm{Li}_{2} \mathrm{FeSiO}_{4-y} \mathrm{~N}_{y}(y=0,0.5$, 1). J Mater Chem, 2011, 21: 10026-10034

52 Kuganathan $\mathrm{N}$, Islam M S. $\mathrm{Li}_{2} \mathrm{MnSiO}_{4}$ lithium battery material: Atomic-scale study of defects, lithium mobility, and trivalent dopants. Chem Mater, 2009, 21: 5196-5202

53 Wu S Q, Zhu Z Z, Yang Y, et al. Effects of Na-substitution on structural and electronic properties of $\mathrm{Li}_{2} \mathrm{CoSiO}_{4}$ cathode material. Trans Nonferrous Met Soc China, 2009, 19: 182-186

54 Fan X Y, Yan L, Wang J J, et al. Synthesis and electrochemical performance of porous $\mathrm{Li}_{2} \mathrm{FeSiO}_{4} / \mathrm{C}$ cathode material for long-life lithium-ion batteries. J Alloys Compd, 2010, 493: 77-80

55 Qian J F, Zhou M, Cao Y L, et al. Template-free hydrothermal synthesis of nanoembossed mesoporous $\mathrm{LiFePO}_{4}$ microspheres for highperformance lithium-ion batteries. J Phys Chem C, 2010, 114: 3477-3482

56 Nuly Y N, Yang J, Zheng Y P, et al. Mesoporous magnesium manganese silicate as a cathode material for rechargeable magnesium batteries (in Chinese). J Inorg Mater, 2011, 2: 130-133

Open Access This article is distributed under the terms of the Creative Commons Attribution License which permits any use, distribution, and reproduction in any medium, provided the original author(s) and source are credited. 